\title{
Ekspresi dan Gestur Penari Tunggal dalam Budaya Media Visual Dua Dimensi
}

\author{
Sri Rustiyanti, Andang Iskandar, Wanda Listiani \\ Institut Seni Budaya Indonesia (ISBI) Bandung \\ Jl. Buah Batu No 212 Bandung, 40265
}

\begin{abstract}
Body Dancer's is used as a media to feel, thoughts, and imagination; representing verbal and nonverbal language; media for nonverbal motion and muscle intelligence; walking and 'walking' as metaphoric-figural phenomenon; and the relation between body-motion-culture-epoch. The dancer expressive movements had motion distillation contains rhythm, so arouse the audience feelings. Dancer performs the slow and smooth motion and also performs the rough, solid, powerul and even the not moving motion. Expression and rythme to create the meaning of the move, so the beauty will come up by itself. The beauty can be enjoyed with the technology of photomotion, thus, gesture and expression from the dancer can be recoreded with soft and high detail with two dimenssion. This research used qualitative methods. This result research is a model of solo body dancer's motion with the technique of photomotion.
\end{abstract}

Keywords: solo dancer, visual culture, two dimension, photomotion

\begin{abstract}
ABSTRAK
Tubuh penari digunakan sebagai media pengungkap perasaan, pikiran, dan imajinasi; pengungkap bahasa verbal dan nonverbal; media ungkap gerak nonverbal dan kecerdasan otot; berjalan dan 'berjalan' sebagai fenomena metaforik-figural; serta sebagai hubungan antara tubuh-gerak-kultur-zaman. Gerak yang dilakukan oleh penari merupakan gerak-gerak ekspresif, gerak yang distilasi mengandung ritme, sehingga mampu menggetarkan perasaan penonton. Penari menyajikan gerak yang halus dan lembut mengalir, juga gerak yang kasar, keras, kuat bahkan dalam diam diam sekali pun. Ekspresi dan irama mewujudkan ungkapan gerak, sehingga akan tampak keindahannya. Keindahan dapat juga dinikmati melalui teknologi photomotion yang canggih, sehingga gestur dan mimik dari para penari bisa terekam begitu detail dan halus, melalui media visual dua dimensi yang hanya mengandalkan indra penglihatan. Penelitian ini menggunakan metode kualitatif. Hasil penelitian ini berupa model gerak tubuh penari tunggal dengan teknik photomotion.
\end{abstract}

Kata kunci: penari tunggal, budaya visual, dua dimensi, photomotion 


\section{PENDAHULUAN}

Eksistensi tubuh penari dalam pertunjukan dapat terjadi saat pertunjukan berlangsung; begitu tari selesai maka proses berlangsungnya pertunjukan pun juga selesai (sifatnya sesaat). Hal ini tentu saja berbeda dengan budaya visual dua dimensi yang bersifat tetap (tidak berubah, abadi) seperti: foto, lukisan, dan gambar. Media visual ini ada yang berupa gambar diam seperti film strip (film rangkai), slides (film bingkai) foto, gambar atau lukisan dan cetakan, gambar atau simbol yang bergerak seperti film bisu dan kartun. Media visual dapat memperlancar pemahaman dan memperkuat ingatan. Visual dapat menimbulkan minat apresiator untuk mengaitkan hubungan antara photomotion dan dunia nyata (tubuh penari dalam pertunjukan). Oleh karena itu seorang penari harus mampu mengungkapkan ekspresi koreografer dari ruang imajinasi ke dalam wujud visual. Rangsang kreatif pada penari dapat berupa rangsang auditif, rangsang visual, rangsang kinestetik, rangsang idesional, dan rangsang peraba (Smith, 1976:32). Rangsangan ini sebagai sesuatu yang membangkitkan pikir, semangat, atau mendorong untuk melakukan sesuatu. Menurut koreografer Sardono W. Kusumo, bahwasannya kriteria seorang penari harus memiliki bakat gerak, seperti yang dijelaskan sebagai berikut:

...keleluasaan tafsir ini memungkinkan penari menyentuh beberapa tingkat kesadaran: perenungan meditatif, ungkapan emosi ekspresif, maupun corporal acrobatic (gerak hebat dan mengagumkan karena ketangkasan tubuh). Sepertinya, pendekatan ini memang naïf, tetapi karena tubuhnya terlatih dari gerak tari alusan dan beragam pola silat, maka keterampilan dalam memainkan kecepatan pengerahan otot kestabilan atau keseimbangan tubuh dan koordinasi gerak serta keseimbangan antara gerak virtuoso, spektakuler serta detil-detil yang intense dari bagian anggota badan, menjadi kekayaan media ungkapan batin. Gerakgerakyang merupakan ekspresi emosi kemudian terasa menjadi ungkapan spontan, karena tubuh yang sering merasakan corporal impulses (gerak atas desakan hati) atau survival instinct (naluri yang terkuat)dari otot-otot tubuh, ketika dorongan tubuh dibawa ke wilayah yang sering berbahaya, bahkan terasa sebagai pengalaman hidupmati yang sering dilatih dalam silat; dari adegan peperangan antara Hanuman dan raksasa; dorongan ekspresi yang membawa tubuh ke atas tembok dinding pembatas panggung secara instingtif berlarian menelusuri tembok tipis, yang tentu saja sangat berbahaya, atau gerak memenuhi ruangan dan berputar berkali-kali hingga pada batas kehabisan tenaga, dan bentuk gerak lainnya (2002:107-108).

Seorang penari, selain kemampuan bakat gerak, memiliki kemampuan mengingat urutan gerak dari awal proses gerak hingga akhir gerak yang dilakukannya, baik itu gerak yang dilakukan dengan improvisasi (spontanitas yang terlatih yang mampu mengendalikan ruang dan waktu) maupun vokabuler gerak yang sudah ditentukan komposisinya. Ia mesti memiliki rasa irama dan musikalitas, kepekaan rasa ruang baik ruang gerak maupun ruang pentas, kemampuan dramatik, dan kemampuan kreatif. Dalam disertasinya, Widaryanto menjelaskan bahwa, gerak dalam eksplorasi ruangnya menciptakan spatial multilayers yang memungkinkan berbagai disiplin menggali kesadaran baru akan terciptanya rasa ruang yang tak pernah berhenti setelah mewujudkan bentuk, tetapi terus cair dan berubah dalam ruang baru yang terus cair seperti yang ada dalam bangun arsitektural Lawang Sewu di Semarang yang menginspirasi menjadi konsep 'kompilasi ruang' yang cair, dan tak sempat membeku dan mewujud menjadi koreografi yang tertutup (2015: 76).

Banyak pendapat definisi tari yang dikemukakan oleh para ahli. Tari terbentuk bukan hanya sekedar susunan gerak penari dari awal hingga akhir, tetapi sebenarnya tari hadir secara utuh dalam suatu kerangka yang dibentuk oleh cabang-cabang seni lainnya, seperti seni rupa, seni musik, tea- 
ter, dan seni visual. Dari beberapa pendapat tentang tari pada dasarnya semua mempunyai penekanannya yang sama yaitu tari sangat erat kaitannya dengan gerak dan ritme. Menurut Langer, bahwasannya gerak tari bukanlah gerak realistik melainkan gerak ekspresif, yang diungkapkan untuk dinikmati dengan rasa (Widaryanto, 1988:6).

\section{METODE}

Tulisan ini merupakan hasil penelitian kualitatif dengan menggunakan pendekatan Peragaan dan Penerapan, dari proses eksplorasi gerak yang dilakukan oleh penari tunggal untuk didokumentasikan dalam bentuk seni visual dua dimensi teknik photomotion. Penelitian kualitatif ini lebih memfokuskan diri kepada kasus kajian yang melibatkan permasalahan yang kecil tetapi secara terperinci, mempunyai sesuatu yang menarik dengan tujuan untuk melihat seni pertunjukan dari budaya seni visual dua dimensi. Metode kajian kasus secara kualitatif, menyatakan bahwa suatu kasus kajian terdiri atas persoalan-persoalan empirikal yang mengkaji suatu fenomena kotemporer antara konteks kehidupan yang sebenarnya (terutama bila sepadan dengan fenomena) dan konteks yang tidak dapat dibuktikan secara jelas (Robert K. Yin, 2003:18).

\section{HASIL DAN PEMBAHASAN}

Penari dalam kebebasan berekspresi, eksplorasi, dan improvisasi dengan melalui beberapa tahap seperti: mendengarkan, mengalami, dan melakukan gerak tari. Elemen-elemen koreografinya yaitu tubuh, ruang, waktu, dan tenaga. Bahwasannya kinestetik tersebut sangat penting menjadi sumber inspirasi untuk eksplorasi membuat tari (Joyce, 1994:74). Pada definisi koreografi, nampak beberapa hal yang krusial, antara lain: berbentuk, dikuasai dengan baik dan mapan, berpola, ada standar gerak yang pakem dan selesai, menempati ruang dengan baik, tidak terlalu formal, frontal atau bahkan juga terlalu praktis, mempunyai citra yang terlalu mengagumkan atau merupakan karya agung, menggunakan dekorasi, terikat gerak yang sudah terpola. Namun penjelasan tersebut secara sepintas memperlihatkan kriteria yang justru mereduksi arti seni itu sendiri. Disisi lain, pertunjukan tari kontemporer memperlihatkan ciri-ciri sebagai berikut: berani menghadapi segala resiko, orisinal, karya yang idenya benar-benar baru dan segar bahkan yang belum terpikirkan oleh orang lain, selalu menghadirkan hal-hal yang muncul di luar perkiraan kita, bebas terus bergerak seperti air mengalir, berani berpenampilan yang sangat minimalis. Hal ini, seperti yang pernah disampaikan oleh Gwennaelle Roulleau dalam Makalah Seminar di STSI Bandung, tanggal 20 Juli 2002.

Keterbatasan ekspresi tari sangat ditentukan oleh kondisi internal dan eksternal penari. Tari adalah salah satu bentuk seni pertunjukan yang mempunyai sifat temporer (sesaat). Tari sebagai seni mempunyai kedudukan yang unik diantara bentuk seni yang lain. Keunikan ini berasal dari kenyataan dasar bahwa tubuh manusia menjadi medium/materi dasar tari. Setiap bentuk seni kecuali akting atau vokal dapat diekspresikan secara bebas sebagai pusat kekuatan ekspresi yang mampu mandiri. Bentuk sebuah syair, lukisan dan patung, tidak dibatasi oleh kemampuan pertumbuhan bentuk tubuh manusia, tetapi mencakup teba yang tak terbatas dari kemungkinan formal unsur lain di luar tubuh manusia. Suara, musik dan lukisan dapat diungkapkan secara berlebihan, sedangkan bentuk tari tidak dapat berlebihan seperti pada bentuk seni yang lain. Tubuh manusia tetap tidak mampu untuk mengarah pada keleluasaan ekspresi seperti seni yang lain karena keterbatasan 
tubuh sebagai pokok media ungkap. Tari tidak pernah mampu melebihi dasar-dasar realisme tertentu. Tari tidak dapat mengungkapkan secara kontradiktif, misalnya dalam lukisan surrealisme, patung, musik atau puisi yang mampu berintegrasi secara mendasar dengan realitas alam. Oleh karena itu, tari terbebas dari gejala ekstrim sehingga tidak seperti seni yang lain yang mampu menggali nilai baru untuk mengungkapkan prinsip estetis dari realitas transfigurasi.

Banyak peristiwa dimana gerak mempunyai maksud yang dapat dimengerti, dengan komunikasi yang non verbal, komunikasi tanpa kata-kata dapat dimengerti apa hendak diekspresikan, seperti: ekspresi kesakitan alis meninggi, pandangan marah penuh intimidasi, jari mengetuk jika menanti tidak sabar dan sebagainya, yang semuanya mempunyai potensi sebagaimana cara hubungan antarmanusia yang terjadi dalam masyarakat, meskipun sulit untuk diketahui secara sadar (Bonni Bird, 1981:3).

\section{Tubuh Penari Tubuh Grotesk}

Dalam pertunjukan sebuah karya seni tari yang ditata oleh seorang koreografer dapat terwujud oleh kehadiran seorang penari. Seorang penari memiliki tubuh sebagai sesuatu yang terbuka dan belum selesai, terus-menerus berubah dan diperbaharui; ia adalah sebuah citraan yang dinamis. Menurut Mikhail Bakhtin, bahwa tubuh 'tubuh grotesk' adalah daging sebagai tempat berproses. Tubuh tidak dipahami sebagai sesuatu yang individual melainkan sesuatu yang universal (Will Derks, t.th: 83). Sosok grotesk merupakan simbolisasi akan perpaduan antara dua jiwa yang bertentangan dalam satu tubuh, grotesk mencitrakan bentuk baru yang mengerikan namun sebenarnya merupakan hasil keselarasan dari dua sisi yang disatupadukan dalam satu bentuk. Grotesk merupakan penyejajaran dua atau lebih entitas yang ada dalam satu tubuh. Dalam karya seni rupa, media photomotion mampu memvisualisasikan hal itu dengan kelebihan medium unsur rupa dibandingkan dengan medium lain, yakni adanya gerak, cahaya dan suara serta durasi (waktu tayang), pencapaian visualisasi yang tumpang tindih layer (lapisan) dengan mudah dan sesuai dapat dilakukan dengan photomotion. Dengan demikian, photomotion mampu menampilkan semua aspek yang dibutuhkan seniman untuk memvisualisasikan gagasannya melalui multimedia ini.

Hawkins menyatakan, bahwa kemahiran dan keinginan untuk mengulang gerak yang spesifik dengan lancar tergantung pada persepsi kinestetik (1988:114). Penari menggunakan kinestetik sebagai rangsang awal untuk bergerak melakukan berbagai variasi gerak, sehingga mampu melakukan gerak baik memahami dengan gerak lokomotor maupun non-lokomotor. Persepsi kinestetik ini berkaitan erat dengan eksplorasi gerak dan kesadaran dalam melakukan gerak tersebut. Akan tetapi, ide penari tunggal dalam kinestetik tetap disesuaikan dengan kreativitas dalam teknik photomotion.

Menurut Jean Paul, grotesk merupakan 'humor destruktif' yang ditujukan tidak hanya untuk menentang aspek negatif dari realita, tetapi juga menentang semua realitas dan dunia yang terbatas secara keseluruhan. Dalam hal ini Jean Paul tidak memisahkan grotesk dengan lelucon;di satu sisi Victor Hugo melihat grotesk sebagai sesuatu yang menimbulkan ketakutan dan ketidakjelasan bentuk, tetapi di sisi lainmenciptakan perasaan riang dan lucu. Menurut Hugo aspek penting dari bentuk grotesk adalah kebesaran atau kedahsyatan. Sementara itu Hegel mendefinisikan grotesk dalam tiga karakteristik,yaitu (1) penggabungan sesuatu yang lazimnya berbeda, (2) dimensi yang dibesar-besarkan dan takterkira,dan (3) penyeragaman anggota atau organ tubuh manusia yang berbeda. Berbeda dengan 
Hegel, E.K. Fischer melihat grotesk sebagai burlesk yaitu keriangan yang muncul dalam bentuk yang ajaibatau menakjubkan. Grotesk yang menjadi unsur dari realisme grotesk dalam tulisan ini adalah grotesk yang muncul dari gagasan Bakhtin tentang carnival atau carnivalesque. Oleh karena itu, dalam membahas realisme grotesk juga dibahas pemahaman tentang carnival atau carnivalesque, serta semangat carnival yang membentuk realisme grotesk. Selain itu dibahas juga prinsip dasar realisme grotesk, imaji dalam realisme groteskdan realisme grotesk yang memanifestasikan 'taksadar kolektif' dalam 'kesadaran kolektif' (Mikhail M. Bakhtin, 1984:42).

Gerak tubuh merupakan persiapan untuk melakukan gerak apa saja yang diinginkan, dan gerak ini dapat dimengerti oleh orang-orang yang terbiasa menggunakan bahasa tubuh, artinya orang-orang yang cukup peka terhadap tari, sehingga timbul tanggapan gerak terhadap tari tersebut. Pengalaman imajinatif dapat memberikan kekuatan gerak dengan memberikan kesempatan mendapatkan pengalaman emosional. Rasa gerak terhadap suatu bentuk tari (pure movement) kemudian dimasukkan dalam bentuk-bentuk gerak yang dapat dimengerti sehingga menjadi bentuk realitas yang praktis. Kegelisahan, ketakutan, cinta dan seterusnya, semua itu perlu dialami dan dapat dinikmati berulang kali.

Teknik ini pada prinsipnya menggunakan foto-foto atau frame by frame foto. Dengan demikian, hasilnya selain didapatkan gambar diam foto-foto, tapi sekaligus dapat menghasilkan film yang dibuat oleh gabungan foto-foto yang saling berhubungan satu sama lainnya.Hasilnya bisa saja sehalus sebuah film, tergantung banyaknya foto yang digabungkan dalam satu detik. Geraknya patah-patah, tetapi menjadi sebuah pilihan yang tepat apabila digunakan untuk menganalisis gerak objeknya, karena objek tidak bergerak begitu cepat tapi terlihat seperti ada jeda di setiap geraknya. Gerak-gerak
Gambar 1. Penari tunggal menjadi objek lebih fokus daripada penari kelompok

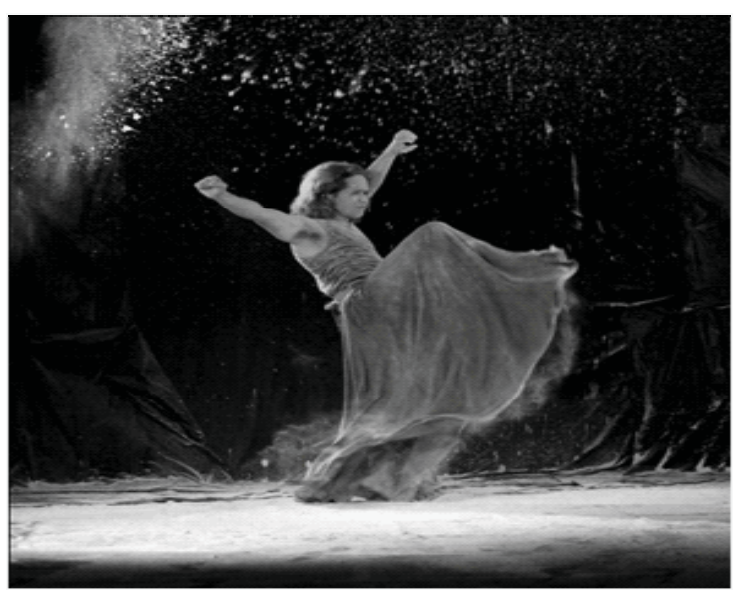

(Fotografer Andang Iskandar, Model Alfiyanto 2014).

tarian Minang direkam, dengan beragam sudut pengambilan, bisa seluruh badan atau close up, bisa high angle, eye level atau low angle sehingga gesture, mimik dari para penari bisa terekam begitu detail dan halus. Fotografi sebagai salah satu media, dipercaya mampu merekam beragam realitas. Realitas sebuah pertunjukan seni tidak terkecuali, oleh karena itu ekplorasi gerak tari yang begitu dinamis, mampu direkam baik oleh fotografi. Teknik fotografi yang digunakan bisa dipakai untuk merekam gerak-gerak tari, langkah demi langkah, bisa dibuat beku atau blur. Salah satu teknik yang sering digunakan dalam merekam gerak adalah dengan teknik photomotion, yang secara harfiah terbangun dari dua kata yaitu photo (foto) yang berarti gambar yang dihasilkan dari proses fotografis dan motion berarti gerak/ bergerak.

Teknologi telah berkembang sedemikian pesat, baik sebagai sebagai penunjang terciptanya gagasan bentuk (aspek intrinsik) maupun juga gagasan pengusung isi (aspek ekstrinsik), yang juga menampilkan fleksibilitas dalam mengusung proses kolaborasi antar berbagai disiplin ranah seni. Di sini dimungkinkan adanya interaksi tubuh dengan misalnya, ruang piktorial lukisan, bila itu merupakan sebuah pameran. Demikian 
Gambar 2. Proses Pemotretan
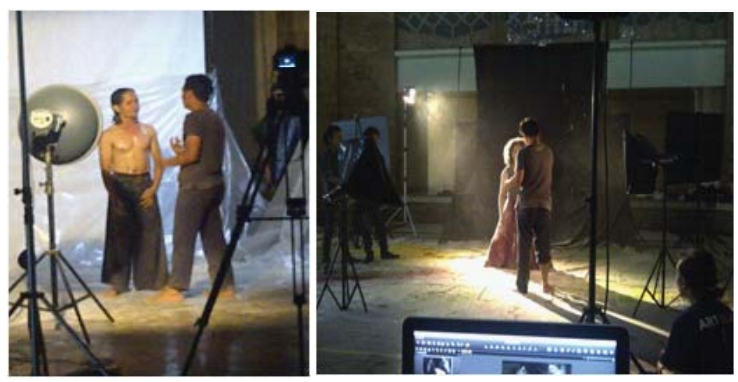

juga dengan penonton yang sedang berada di garis imajinasi pentas panggung yang bisa berubah-ubah, di mana tubuh penari bisa masuk dalam wilayah area penonton. Kekaburan garis batas wilayah pentas dan penonton bisa menjadi rangsang interaktif antar keduanya dalam menciptakan ruangruang baru sebuah pertunjukan.

Sebaliknya photomotion penari kelompok terbangun dari satu-kesatuan penari yang mempunyai kekuatan secara total. Bahkan dalam pertunjukan penari kelompok yang menggunakan desain paralel (berkesinambungan) tidak akan terwujud bentuk gerak jika dilakukan oleh penari tunggal. Seperti pada gambar 2, yang menggambarkan kekuatan penari terdapat pada kebersamaan penari dalam kelompok dan tidak ada yang ditokohkan, semua penari mempunyai peran yang sama.

\section{Transformasi Estetika Tubuh Penari ke Photomotion}

Estetika adalah ilmu yang mempelajari segala sesuatu yang berkaitan dengan keindahan dari aspek wujud, bobot, dan penampilan (Djelantik, 1999:17). Rasa keindahan, nikmat-indah-bagus yang terjadi pada manusia timbul karena peran dari pancaindra. Manusia memiliki pancaindra dengan kemampuan untuk menangkap rangsangan dari luar dan meneruskannya ke dalam dirinya. Rangsangan dari luar tersebut baik rangsang auditif, rangsang visual, rang- sang kinestetik, rangsang idesional, maupun rangsang peraba, kemudian diolah menjadi sebuah kesan. Selanjutnya kesan itu dibawa lebih jauh ke dalam diri, sehingga perasaan dapat menikmatinya. Penangkapan kesan dari luar, yang menimbulkan nikmat-indahbagus terwujud melalui dua dari lima jenis pancaindra, yaitu melalui indera mata dan indera telinga baik secara langsung maupun tidak langsung. Kesan diterima menjadi sebuah yang berurutan dari sensasi-persepsiimpresi-emosi-interpretasi-ekspresi. Proses panjang ini kemudian dituangkan menjadi sebuah photomotion.

Proses penangkapan sense yang diterima manusia bersumber dari mata yang kita sebut kesan visual, sedangkan yang melalui telinga disebut kesan akustis atau auditif. Dalam proses kesan visual memungkinkan terjadinya proses relatif lebih pendek, yaitu dari penerimaan rangsangan keindahanyang didapat dari sumber-sumber visual yang ada sebelumnya, dan bentuk-bentuk itu adalah yang dipilih sesuai dengan imaginasi fotografer, kemudian menjadi bahan referensi bahan untuk diinterpretasikan kembali dan dituangkan dalam ide dan gagasan bentuk visual baru. Dan disinilah memungkinkan terjadinya 'morfologi estetik', seperti karyakarya fotografi yang telah dihasilkan akan mempengaruhi dan memberikan inspirasi terhadap karya yang akan dihasilkan.

Sensasi adalah proses penerimaan rangsang melalui penginderaan. Rangsangan terdiri atas energi fisik seperti cahaya, suara, dan panas. Rangsangan dideteksi oleh sel reseptor khusus pada organ indra seperti mata, telinga, kulit, hidung, dan lidah. Ketika rangsangan ini sampai ke otak, informasi bergerak ke bagian yang berhubungan pada ingatan visual, ingatan baru sebagai pemrosesan input indera. Sensasi yang diterima dengan mata belum mempunyai makna. Pada tahap ini belum dapat dilihat apa yang ditangkap oleh mata. Pada orang yang fungsi otaknya kurang cepat, atau yang kurang 
berpengalaman, antara sensasi dan persepsi berselang sejenak waktu. Pada orang dewasa tidak memerlukan waktu, asosiasi dari sensasi yang baru dengan pengalaman yang lalu berlangsung seketika. Agar proses penerimaan ini baik, harus ada objek yang diamati atau kekuatan stimulus, kepastian alat indera yang cukup baik serta syaraf yang baik, serta pengalaman dan lingkungan budaya.

Tahap sensasi yang telah berkesan disebut persepsi. Sebuah persepsi adalah konsep yang sangat penting dalam apresiasi, karena melalui persepsilah manusia memandang segala isi dunia. Persepsi berbeda dengan sensasi. Persepsi dipengaruhi oleh ketersediaan informasi sebelumnya; ketiadaan informasi ketika seseorang menerima stimulus yang baru bagi dirinya akan menyebabkan kekacauan dalam mempersepsi; kebutuhan seseorang akan cenderung mempersepsikan sesuatu berdasarkan kebutuhannya saat itu, dan pengalaman masa lalu. Faktor psikologis lain yang juga penting dalam persepsi adalah emosi-impresi-konteks. Emosi akan mempengaruhi seseorang dalam menerima dan mengolah informasi pada suatu saat, karena sebagian energi dan perhatiannya menjadi figure adalah emosinya tersebut. Impresi merupakan stimulus yang salient (menonjol), akan lebih dahulu mempengaruhi persepsi seseorang, sedangkan konteks meskipun pada urutan terakhir, namun justru dapat memungkinkan menjadi faktor yang paling penting. Persepsi itu secara langsung juga menggerakkan proses asosiasi-asosiasi mekanisme lain, seperti komparasi (perbandingan), diferensiasi (perbedaan), analogi (persamaan) dan sintesis (penyimpulan). Kemampuannya menghasilkan pengertian yang lebih luas dan mendalam, yang awalnya hanya merupakan kesan (persepsi) sekarang menjadi keyakinan (impresi). Perbedaan impresi dengan persepsi, bahwa yang sudah bersifat impresi setiap waktu dapat diingatkan kembali, karena su- dah tertanam di dalam wilayah kesadaran kita. Keyakinan-keyakinan yang terdahulu ada kaitannya, atau ada relevan terhadap yang baru (keterkaitan yang khas dan penting). Tahap Impresi ini dapat dikatakan juga dalam tahap memori. Dengan pengkaitan ini terjadilah dua proses yang bersamaan yaituemosidalam bidang perasaan dan interpretasi dalam bidang pemikiran. Emosi, adalah sesuatu yang tidak dapat dielakkan dan dalam mengapresiasikarya seni memang sangat diperlukan. Tanpa adanya emosi tidak akan terjadi proses apresiasi seni (Deddy Mulyana, 2006).

Keindahan yang ada dalam karya seni dan keindahan alam dapat dinikmati hanya oleh manusia yang memiliki emosi. Bahwasannya emosi-nikmat-indah sifatnya berbeda dengan perkataan sehari-hari yangkita kenal dengan sebutanemosi, yakni perasaan yang meluap tanpa dapat dikendalikan, misalnya jengkel, kecewa, panik, antusias, dan gembira. Sebaliknya, interpretasi menyangkut aktivitas dari daya pikir akibat impresi yang masuk ke wilayah kesadaran. Interpretasi merupakan fungsi aktif intelektualitas manusia, yang dilengkapi dengan emosi, akan menghasilkan pengertian yang lebih mendalam tentang apa yang dipersepsi. Keyakinan yang semakin dimengerti, bukan berarti pemikiran berhenti berfungsi, tetapi akan terus memikirkan dan merenungkan tentang interpretasi yang telah dilakukan. Apresiasi, merenungkan tentang pengertian itu atau yang telah diinterpretasikan, mempersoalkan interpretasi itu, menimbangnya terhadap fakta-fakta yang lain, mempertimbangkan kebenaran dan sampai di mana maknanya, adalah fungsi intelek yang berganda yang dirumuskan dengan kata apresiasi. Pada dasarnya semua pengertian yang menambah pengetahuan dan pengalaman kita, adalah sesuatu yang kita hargai to appreciate (Djelantik, 1999:88-91). Aktivitas intelek semacam ini menjadikan penikmatan keindahan dalam seni keseluruhannya se- 
bagai objek atau benda untuk diteliti. Aktivitas intelektualitas ini disebut objektivisasi dari peristiwa yang berlangsung.

\section{PENUTUP}

Photomotion hasil pemotretan tubuh penari tunggal, sebuah pendekatan analisis teks, yang dalam pengertian luasnya, didefinisikan sebagai pesan-pesan, baik yang menggunakan tanda verbal maupun tanda visual yang menghasilkan teks verbal dan teks visual. Dengan begitu teks seni seperti: foto, patung, lukisan, tari, dan teater termasuk dalam kelompok teks visual. Media dua dimensi merupakan media yang hanya dapat dilihat dari dua sisi saja yaitu panjang dan lebar, tetapi meskipun seperti itu media dua dimensi dengan teknik photomotion cukup berpengaruh dalam apresiasi derajat tingkat kedua, sedangkan apresiasi langsung pada tubuh penari tunggal merupakan derajat tingkat pertama. Apresiasi memberi kepuasan intelektual, mental, dan spiritual. Impresi sebagai proses dalam memori dapat diingat dan kemudian dikeluarkan menjadi sebuah pikiran, baik berpikir secara realistik (interpretasi) yang ditandai dengan berpikir secara sistemik, maupun berpikir secara logika rasa (emosi) yang biasanya dilakukan dengan menyendiri, berimaginasi, dan kontemplasi.

Penyampaian elemen tari oleh tubuh penari tunggal dilakukan secara bebas melalui daya imajinasi dalam mengeluarkan ide gerak yang spontan dan digabungkan dengan elemen tari yang menjadi tumpuan penaritunggal. Gerakyang menggunakan variasi komponen tari merupakan gabungan ideal yang diinginkan oleh fotografer, sehingga tercipta komunikasi seni antara penari tunggal dan fotografernya. Dengan demikian fotografer tidak seharusnya mematikan kreativitas penari, tetapi perlu juga memberikan kebebasan daya cipta dan mendorong penari tunggal bereksplorasi dalam melakukan gerak untuk diambil momen-momen yang penting dalam teknik photomotion.

Apa yang kemudian penting adalah kesadaran tempo yang melibatkan cepat atau lambatnya suatu gerakpenari tunggalyang berkaitan dengan unsur gerak waktu, tenaga, dan ruang yang dapat dilihat dengan jelas dari permindahan gerakyangsatu ke gerak yang lainnya.Kesadaran anggota tubuh adalah kemampuan penari untuk mengetahui dan memahami gerak anggota tubuhnya sendiri menjadi fokus perhatian. Kesadaran ini bertujuan untuk menghasilkan berbagai macam gerak dan potensi tubuhuntuk bergerak. Kesadaran arah gerak untuk memahami dan mengaplikasikan konsep, seperti arah diagonal, ke depan, ke belakang, ke kiri, atau ke kanan, dan sebagainya. Maka, ketika penari tunggal melakukan suatu gerak dengan menggunakan anggota tubuhnya, penari melakukan gerak berdasarkan pada gerakan anggota tubuh dan mengetahui fungsi dari tubuhnya tersebut. Di sini, penari mengetahui arah geraknya, sehingga ketika fotografer menginginkan kedudukan arah gerak, seperti tangan ke depan dan kaki ke kiri dilakukan secara serentak, maka penari telah mengetahui apa harus dilakukannya.

\section{Daftar Pustaka}

A.AM. Djelantik

1999 Estetika sebuah Pengantar. Bandung: MSPI.

\section{Bakhtin, Mikhail M}

1984 Rabelais and His World. Diterjemahkan oleh Helene Iswolsky. "Tvorchestvo Fransua Rable". Bloomington: Indiana UP.

Bird, Bonni

1981 Dance an Art in Academi. Yogyakarta: Akademi Seni Tari Indonesia. 
Deddy Mulyana

2006 Ilmu Komunikasi Suatu Pengantar. Bandung: Remaja Rosdakarya.

Derks, Will

t.th 'Tubuh Liar: Realisme Grotesk dalam Cerita Melayu', dalam Kalam: Menguak Tubuh. Jakarta: Yayasan Kalam.

FX. Widaryanto

2015 'Ekokritikisme Sardono W. Kusumo: Gagasan, Proses Kreatif, dan TeksTeks Ciptaannya'. Disertasi Program Doktor. Surakarta: Institut Seni Indonesia.

1988 Problematika Seni. Alih bahasa Problems of Art oleh Suzane K. Langer. Bandung: Akademi Seni Tari Indonesia.

Hawkins, Alma M.

1988 Creating Through Dance. New Jersey: Princeton Book Company.
Joyce, Mary

1994 First Steps in Teaching Creative Dance to Children (2nd ed). Mountain View, CA: Mayfield Publishing Co.

Sardono W. Kusumo

2002 'Hanoman, Tarzan, Dan Pithecan thropus Erectus', dalam Jurnal, MenimbangPraktek Pertukaran Budaya: Kolaborasi, Misi, Sumber, \& Kesempatan. Dialog Art Summit Indonesia III. Jakarta: MSPI.

Smith, Jacqueline

1976 Dance Composition A Practical Guide for Teachers. Terjemahan Ben Suharto. 1985. Komposisi Tari: Sebuah Petunjuk Praktis bagi Guru. Yogyakarta: Ikalasti.

Yin, Robert. K

2003 Case Study Research: Design and Methods. SAGE Publication. 